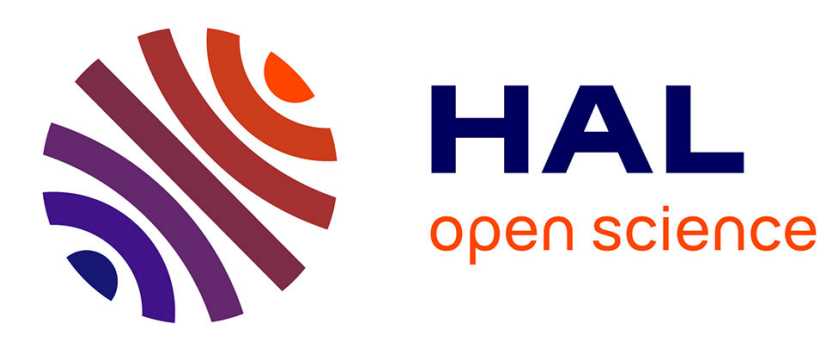

\title{
Glyoxal Induced Atmospheric Photosensitized Chemistry Leading to Organic Aerosol Growth
}

S. Rossignol, K. Z. Aregahegn, L. Tinel, L. Fine, B. Noziere, C. George

\section{To cite this version:}

S. Rossignol, K. Z. Aregahegn, L. Tinel, L. Fine, B. Noziere, et al.. Glyoxal Induced Atmospheric Photosensitized Chemistry Leading to Organic Aerosol Growth. Environmental Science and Technology, 2014, 48, pp.3218-3227. 10.1021/es405581g . hal-01057392

\section{HAL Id: hal-01057392 \\ https://hal.science/hal-01057392}

Submitted on 13 Feb 2015

HAL is a multi-disciplinary open access archive for the deposit and dissemination of scientific research documents, whether they are published or not. The documents may come from teaching and research institutions in France or abroad, or from public or private research centers.
L'archive ouverte pluridisciplinaire HAL, est destinée au dépôt et à la diffusion de documents scientifiques de niveau recherche, publiés ou non, émanant des établissements d'enseignement et de recherche français ou étrangers, des laboratoires publics ou privés. 


\title{
Glyoxal Induced Atmospheric Photosensitized Chemistry Leading to Organic Aerosol Growth
}

\author{
Stéphanie Rossignol, Kifle Z. Aregahegn, Liselotte Tinel, Ludovic Fine, Barbara Nozière, \\ and Christian George*
}

Université de Lyon, Université Lyon 1, Lyon, F-69626, France and CNRS, UMR5256, IRCELYON, Institut de Recherches sur la Catalyse et l'Environnement de Lyon, Villeurbanne, F-69626, France

\begin{abstract}
In recent years, it has been proposed that gas phase glyoxal could significantly contribute to ambient organic aerosol (OA) mass through multiphase chemistry. Of particular interest is the reaction between glyoxal and ammonium cations producing light-absorbing compounds such as imidazole derivatives. It was recently shown that imidazole-2-carboxaldehyde (IC) can act as a photosensitizer, initiating aerosol growth in the presence of gaseous volatile organic compounds. Given the potential importance of this new photosensitized growth pathway for ambient $\mathrm{OA}$, the related reaction mechanism was investigated at a molecular level. Bulk and flow tube experiments were performed to identify major products of the reaction of limonene with the triplet state of IC by direct $( \pm)$ ESI-HRMS and UPLC/ $( \pm)$ HESI-HRMS analysis. Detection of recombination products of IC with limonene or with itself, in bulk and flow tube experiments, showed that IC is able to initiate a radical chemistry in the aerosol phase under realistic irradiation conditions. Furthermore, highly oxygenated limonene reaction products were detected, clearly explaining the observed OA growth. The chemistry of peroxy radicals derived from limonene upon addition of oxygen explains the formation of such lowvolatile compounds without any traditional gas phase oxidant.

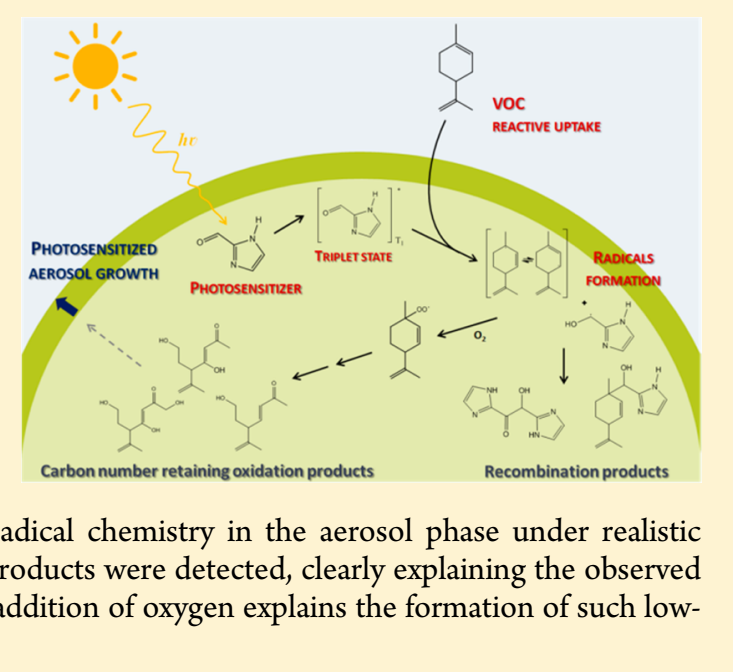

\section{INTRODUCTION}

Organic aerosol (OA) represents an important fraction (20 to $90 \%$ in mass) of the total budget of atmospheric aerosols, and its oxygenated fraction, considered as mainly of secondary origin, is significant in many locations. ${ }^{1,2}$ A detailed knowledge of the formation and aging pathways of secondary organic aerosol (SOA) is thus critical to accurately assess their impact on visibility, health and climate. Traditionally, SOA formation has been described as proceeding only through gas phase oxidation of volatile organic compounds (VOC) forming low volatility products, which then partition between gas and particulate phases. However, in recent years it has become increasingly apparent that this simple model was not sufficient to accurately reproduce the OA mass observed and its oxidation state. ${ }^{2,3}$ Important efforts were thus made to explain and close the gap between observations and modeling. The classical approach including only anthropogenic and biogenic VOCs (aromatic compounds, isoprene, limonene, pinene, and so forth) has been widened to include semi- and low-volatile precursors, thus bringing the calculated SOA masses closer to observations. $^{4-7}$ However, in addition to these condensation processes, it has also been pointed out that very volatile compounds such as glyoxal can significantly contribute to SOA mass through multiphase chemistry. As glyoxal and other small dicarbonyl species are emitted in large amounts during oxidation of VOCs, ${ }^{8}$ the existence of condensed phase sinks for these gases is indeed able to explain an important part of the missing SOA mass in models, ${ }^{9-12}$ for example, at least $15 \%$ of the SOA mass in the specific case of glyoxal uptake in Mexico city (MCMA-2003 campaign). ${ }^{10}$

It was shown that glyoxal uptake into droplet and water containing aerosol particles leads to the formation of low volatility species, and thus to SOA formation, through three main processes: (1) oligomer formation, (2) photochemical radical oxidation, and (3) condensation with ammonium cations $\left(\mathrm{NH}_{4}^{+}\right)$and amines leading to nitrogen-containing products. ${ }^{13,14}$ Oligomer formation occurs via acetal formation (C-O-C bond formation)..$^{13,15-17}$ Photochemical oxidation of glyoxal is initiated by hydrogen abstraction by $\mathrm{OH}$ radical and leads to the formation of small organic acids, such as glyoxylic acid or formic acid, but also to the formation of larger oxygenated products through organic radical recombination in concentrated solutions. ${ }^{13}$ These two pathways (oligomerization and photochemical oxidation), are particularly interesting as they form low volatility products that can match with the high oxygen to carbon ratio (O/C) detected in ambient aerosols, not yet well reproduced in models. Although this condensation pathway is certainly minor relative to SOA mass formation, ${ }^{18}$ glyoxal reactivity toward ammonium cations and amines has

Received: December 17, 2013

Revised: February 11, 2014

Accepted: February 20, 2014 
gained interest in recent years due to the fact that it leads to the formation of compounds absorbing in the UV-visible region. ${ }^{17,19,20}$ Nozière et al. ${ }^{17}$ showed that the reaction of glyoxal with $\mathrm{NH}_{4}{ }^{+}$ions indeed forms light-absorbing nitrogencontaining species. Among these nitrogen-containing products, Galloway et al. $^{21}$ have identified $1 \mathrm{H}$-imidazole-2-carboxaldehyde (IC), which absorbs UV radiation at $\lambda=290 \mathrm{~nm}$. A number of laboratory studies have further confirmed the formation of products bearing an imidazole ring, ${ }^{22,23}$ including IC. ${ }^{18,24}$ It was also shown that these minor products were nevertheless able to impact optical and radiative properties of ambient aerosols. $^{23}$

However, the formation of such light absorbing species can also induce new photochemical processes within the aerosol particles and/or at the gas/particle interfaces. Monge et al. ${ }^{25}$ found experimental evidence of a photoinduced pathway for organic aerosol growth. The growth was observed when seeds containing light absorbing material [e.g., humic acid or 4(benzoyl)benzoic acid] were exposed to light and gaseous VOCs, suggesting a reactive uptake for the latter under irradiation. Interestingly, a similar observation was made with IC-containing seeds by Aregahegn et al. ${ }^{26}$ who, based on the works of Canonica et al., ${ }^{27}$ suggested a photosensitized mechanism where radical chemistry is initiated by the reaction of a VOC with the triplet state of IC.

Given of the potential importance of this new photosensitized pathway for SOA production and aging, we aimed to understand the reaction mechanism leading to the aerosol growth as reported by Aregahegn et $\mathrm{al}^{26} \mathrm{~A}$ first series of experiments investigated the reactivity of the IC triplet state toward limonene, chosen as a key VOC compound, using laser flash photolysis. Bulk experiments were then carried out to identify the products of the reaction between the IC triplet state and limonene, using direct electrospray ionization (positive and negative modes) coupled to high resolution mass spectrometry $[( \pm)$ ESI-HRMS $]$ and ultraperformance liquid chromatography coupled with heated $( \pm)$ ESI-HRMS [UPLC/( \pm HESI-HRMS]. Finally, aerosols produced in flow tube experiments, similar to those of Aregahegn et al., ${ }^{26}$ were analyzed by UPLC/ $( \pm)$ HESI-HRMS and compared with the bulk experiments to identify the organic products responsible for SOA growth.

\section{EXPERIMENTAL SECTION}

Laser Flash Photolysis Experiment. The reactivity of excited IC toward limonene was investigated using a classical laser flash photolysis apparatus. ${ }^{28}$ IC triplet state was produced upon excitation under UV irradiation and its deactivation over time was followed by monitoring its absorption in the presence or absence of limonene. The photolysis excitation source was the third harmonic ( $266 \mathrm{~nm}$, pulse width $\sim 7 \mathrm{~ns}$ ) of an Nd:YAG laser (Surelite II 10, Continuum, U.S.) operated in a single-shot mode. During these experiments, the laser pulse energy was limited at $20 \mathrm{~mJ}$ per pulse to reduce photolysis of the photosensitizer. It was experimentally observed that under this energy threshold the upper limit of the fraction of IC depleted by each pulse was negligible $(<0.14 \mu \mathrm{M})$. Ground state IC extinction coefficient was calculated as $\varepsilon_{266 \mathrm{~nm}}=4698 \mathrm{M}^{-1}$ $\mathrm{cm}^{-1}$. The laser output passed through the aperture in the short axis (4 mm path length) of a fully masked quartz flow cell. The working water-acetonitrile (1:1) solutions containing IC (0.25 $\mathrm{mM}, 97 \%$, Sigma-Aldrich, U.S.) and various amounts of limonene (0 mM, $4 \mathrm{mM}, 8 \mathrm{mM}$ and $12 \mathrm{mM},(R)-(+)$-limonene
97\%, Sigma-Aldrich, U.S.) were deoxygenated for at least $1 \mathrm{~h}$. They were introduced into the flow cell (volume of $450 \mu \mathrm{L}$ ) by means of a peristaltic pump, with a flow rate of $1.6 \mathrm{~mL} \mathrm{~min}^{-1}$, ensuring a complete purge of the exposed volume every $17 \mathrm{~s}$. This limited the exposure of the introduced solution to 3-4 laser shots and maintained a constant temperature in the flow cell. All connections on the apparatus were made from either glass or PTFE tubing, ensuring a clean liquid flow. The transient absorption of the excited IC produced upon $266 \mathrm{~nm}$ excitation was followed by means of time-resolved absorption spectroscopy at $330 \mathrm{~nm}$ in the absence and presence of limonene. The analyzing light, provided by a $75 \mathrm{~W}$ highpressure Xenon arc lamp (LOT-Oriel, Germany), passed through the two apertures of the long axis of the flow cell ( 1 $\mathrm{cm}$ path length). The light was then collected by a $1 / 4 \mathrm{~m}$ monochromator (DK240, Spectral Products, U.S.) equipped with a 2400 grooves $/ \mathrm{mm}$ grating and detected by a photomultiplier (PMT, H7732-10, Hamamatsu, Japan). The PMT signal was passed through a high-speed current amplifier/ discriminator (Femto, Germany) and the AC and DC component recorded on a $300 \mathrm{MHz}$ oscilloscope (TDS3032c, Tektronix, U.S.). The digitalized signal was then transferred to a computer for further processing. The analysis of transient absorbance decays as well as the fitting was performed on OriginPro (version 8.5).

Bulk Experiments. A water-acetonitrile solution (1:1, v/v, Elga ultrapure water, France/Fischer Chemical, U.K.) containing IC ( $1 \mathrm{mM}, 97 \%$, Sigma-Aldrich, U.S.) and limonene (10 $\mathrm{mM},(R)-(+)$-limonene 97\%, Sigma-Aldrich, U.S.) was placed in a small cylindrical quartz reactor (volume of $15 \mathrm{~mL}$ ) and exposed to light in a box equipped with 7 UV-lamps (Cleo 20 W, emission range 280-400 nm, Philips, Netherlands) for $23 \mathrm{~h}$. At different intervals, two $400 \mu \mathrm{L}$ samples were diluted by a factor 25 , in a water-acetonitrile solution $(1: 1, \mathrm{v} / \mathrm{v})$ or pure water for direct analysis in ( \pm ESI-HRMS and analysis by $\mathrm{UPLC} /( \pm)$ HESI-HRMS, respectively.

Flow Tube Experiments. Photosensitized growth of aerosols was carried out using a horizontal double wall aerosol flow tube made of Pyrex ( $13 \mathrm{~cm}$ i.d. $\times 152 \mathrm{~cm}$ length) kept at $293 \pm 1 \mathrm{~K}$ by means of a circulating water bath. The carrier gas was dry air (purity $99.9990 \%$, Air Liquide, France), introduced at a total flow rate of $0.4 \mathrm{~L} \mathrm{~min}^{-1}$ allowing an aerosol residence time of $50 \mathrm{~min}$. The flow tube was surrounded by 7 UV-lamps (Cleo, Philips, Netherlands) with a continuous emission spectrum over $300-420 \mathrm{~nm}$ and a total irradiance of $3.7 \times$ $10^{16}$ photon $\mathrm{cm}^{-2} \mathrm{~s}^{-1}$. A complete description of this aerosol flow tube setup is given elsewhere. ${ }^{25}$

For physical characterization of the aerosol growth, a monodispersed aerosol ("seed particles") was generated from an aqueous solution containing IC (1.3 mM, 97\%, SigmaAldrich, U.S.) and ammonium sulfate (0.95 mM, 99.0\%, SigmaAldrich, U.S.). The atomized solution (atomizer 3076, TSI, U.S.) was then dried using a Silica gel 20 diffusion drier and an initial seed particles diameter of $50 \mathrm{~nm}$ was selected using a Differential Mobility Analyzer (DMA 3081, TSI, U.S., impactor size $0.0588 \mathrm{~cm}$, aerosol flow $=0.3 \mathrm{~L} \mathrm{~min}^{-1}$, sheath flow $=3 \mathrm{~L}$ $\left.\min ^{-1}\right)$. This monodispersed aerosol contained typically 5000 particles $\mathrm{cm}^{-3}$ and corresponded to a total mass of a few $\mu \mathrm{g}$ $\mathrm{m}^{-3}$. It was flown into the reactor where it was exposed to gaseous limonene and, when required, to UV light. A limonene concentration of around $0.9 \mathrm{ppm}$ was generated using a permeation tube placed in a temperature controlled oven (Dynacal, Valco Instruments Co. Inc., U.S., using VICI 


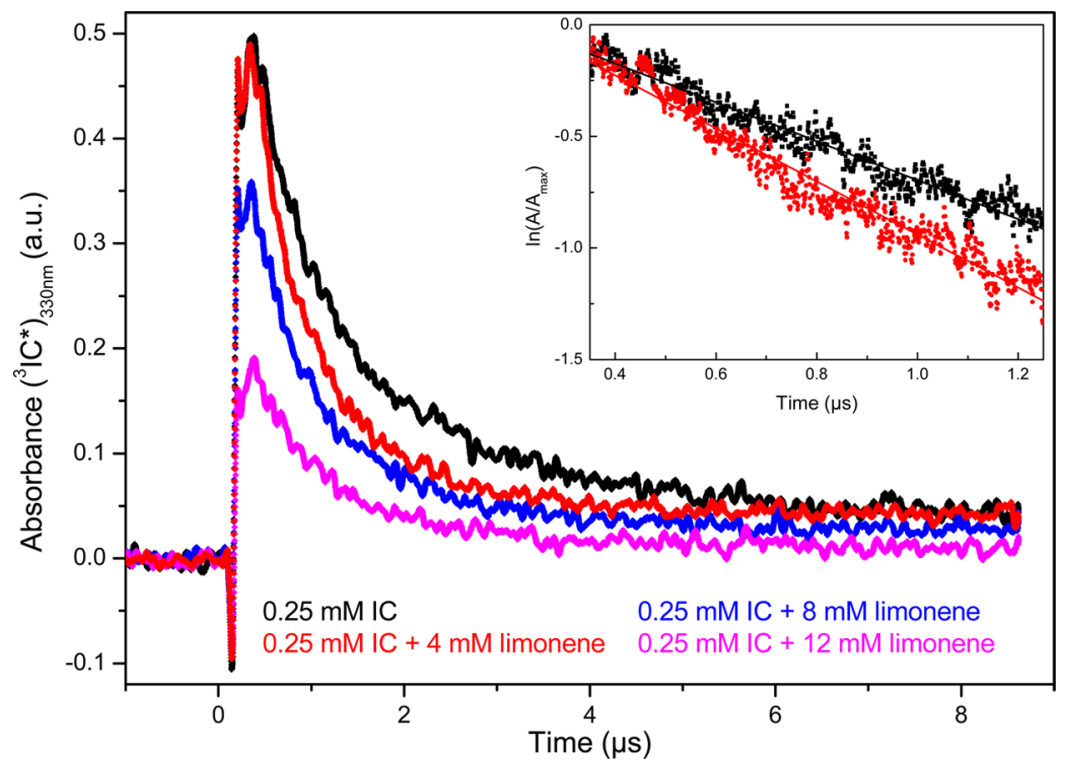

Figure 1. Transient triplet-triplet absorption of the excited IC followed at $330 \mathrm{~nm}$ in a water-acetonitrile (1:1) mixture in the absence of limonene as a quencher (black), in the presence of $4 \mathrm{mM}$ of limonene (red), $8 \mathrm{mM}$ of limonene (blue) and $12 \mathrm{mM}$ of limonene (pink). Inset: linear fitting of corresponding $\ln \left(A / A_{\max }\right)=f(t)$. $A_{\max }$ : maximum absorbance observed for each data series.

Metronics, U.S., Dynacalibrator, model 150). The particle size distribution and concentration obtained at the outlet of the flow tube were monitored using a Scanning Mobility Particle Sizer (SMPS 3080, TSI, U.S.), consisting of a DMA (TSI 3081) and a Condensation Particle Counter (CPC, TSI 3776).

For the aerosol sampling and subsequent chemical analysis, we decided to increase the seed particles concentration in order to improve the signal-to-noise ratio of the ESI-HRMS. At the flow tube inlet, the DMA was removed to generate a polydispersed dry aerosol. Particles were then collected at the flow tube outlet on a Teflon filter $(47 \mathrm{~mm}$ Fluoropore membrane filters, $0.45 \mu \mathrm{m} \mathrm{FH,} \mathrm{Merk} \mathrm{Millipore,} \mathrm{U.S.)} \mathrm{using} \mathrm{a}$ stainless steel filter holder (Aerosol standard filter holder, 47 $\mathrm{mm}$, Merk Millipore, U.S.). Two experiments of $16 \mathrm{~h}$ were systematically and consecutively performed; first, a "blank" consisting of introducing both seed particles and gaseous limonene but without light, and second, a "sample" was collected with the light on. The filters were subsequently solvent extracted under ultrasonication $(40 \mathrm{~min})$ in $7 \mathrm{~mL}$ of a water-acetonitrile solution $(4: 6, \mathrm{v} / \mathrm{v})$ in an Erlenmeyer, maintained at low temperature in an ice bath. Extracts were then concentrated to $1 \mathrm{~mL}$ under a gentle stream of nitrogen and were subsequently analyzed by UPLC/( \pm HESI-HRMS.

ESI- $( \pm)$ HRMS and UPLC/( \pm HESI-HRMS Analysis. The UPLC/( \pm HESI-HRMS system comprised a Dionex Ultimate 3000 ultraperformance liquid chromatograph (UPLC, Thermo Scientific, U.S.) coupled to a Q-Exactive high resolution mass spectrometer (HRMS, Thermo Scientific, U.S.) equipped with a heated electrospray ionization (HESI) source. Half of the bulk samples (diluted in water-acetonitrile mixture) were analyzed by direct infusion of the diluted solutions into the nonheated electrospray source (ESI- $( \pm)$ HRMS analysis) at a flow rate of $30 \mu \mathrm{L} \mathrm{min}{ }^{-1}$. Source voltages of $+3.5 \mathrm{kV}$ and -2.6 $\mathrm{kV}$ were applied for the positive $(+)$ and negative (-) ionization modes, respectively. The remaining bulk fraction and the flow tube samples were analyzed by means of UPLC/ ( \pm HESI-HRMS. The chromatograph was equipped with a HSS T3 Acquity UPLC column $(1.8 \mu \mathrm{m}, 2.1 \times 100 \mathrm{~mm})$. The mobile phase was (A) acidified water (Fischer Chemical, U.K.,
$+0.1 \%$, v/v, formic acid, Sigma-Aldrich, U.S.) and (B) acidified acetonitrile (Fischer Chemical, U.K., $+0.1 \%$, v/v, formic acid, Sigma-Aldrich, U.S.). A 16 min gradient was applied: eluent (B) was kept at $1 \%$ for 2 min and was then increased to $90 \%$ in 10 min, this ratio was maintained for 2 min before returning to the initial condition for $2 \mathrm{~min}$. The flow rate was $0.3 \mathrm{~mL} \mathrm{~min}{ }^{-1}$. Source voltages of $+3.7 \mathrm{kV}$ and $-3.0 \mathrm{kV}$ were applied for the positive (+) and negative ( - ) ionization modes respectively. All acquisitions were performed in full MS mode with a scan ranging from $\mathrm{m} / z 50$ to $\mathrm{m} / z 750$ and a resolution set to 140 000. Specific $\mathrm{MS}^{2}$ spectra were acquired in direct infusion mode applying a normalized collision energy level of $35 \%$. The data were processed using Xcalibur 2.2 software. The Q-Exactive mass spectrometer was mass calibrated using commercial Calmix solutions (Thermo Scientific, U.S.). To achieve good accuracy for low masses ( $<4 \mathrm{ppm})$ commercially used mass lists were completed with mass 74.09643 for the positive mode and masses 59.01385 and 514.28440 for the negative mode. All of the exact mass assignments to chemical formula were done considering carbon, hydrogen, oxygen, nitrogen, sodium, and potassium as potential elements and with a mass accuracy below $4 \mathrm{ppm}$. All of the proposed chemical formulas comply with the octet rule (i.e., an integer double bond equivalent) for the related neutral compounds.

\section{RESULTS AND DISCUSSION}

Triplet State Chemistry of IC. This first series of experiments was performed to verify the hypothesis proposed by Aregahegn et al. ${ }^{26}$ that the excited triplet state of IC could react with limonene. The formation of an IC triplet state under UV-irradiation was demonstrated elsewhere by Tinel et al. ${ }^{29}$ The triplet-triplet IC absorption monitored at $330 \mathrm{~nm}$ showed a monoexponential decay. By adding increasing amounts of limonene to the IC containing solution, the decay of the transient absorption was observed to be faster (Figure 1). These results confirmed that limonene quenches the IC triplet state, i.e., introducing a reaction that may proceed via electron or hydrogen transfer in agreement with Aregahegn et al. ${ }^{26}$ 


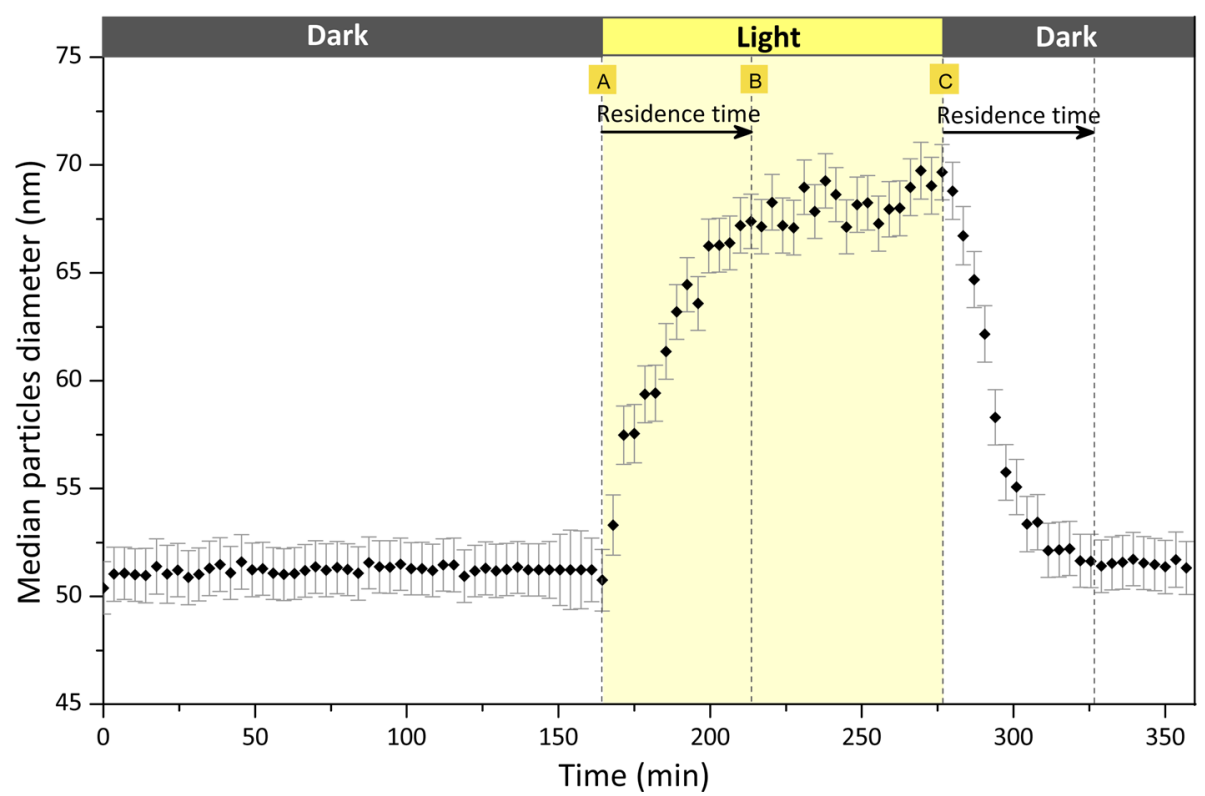

Figure 2. Temporal evolution of the median diameter of particles during a flow tube experiment. Monodisperse seed particles (IC/ammonium sulfate) were exposed to gaseous limonene continuously $(0.9 \mathrm{ppmv})$ and to UV light between 165 and $277 \mathrm{~min}$. Error bars correspond to 2 times the geometrical standard deviation. Arrows and dotted vertical lines mark the theoretical aerosol residence time at two critical points: when the lamps were switched on (A) and off (C).

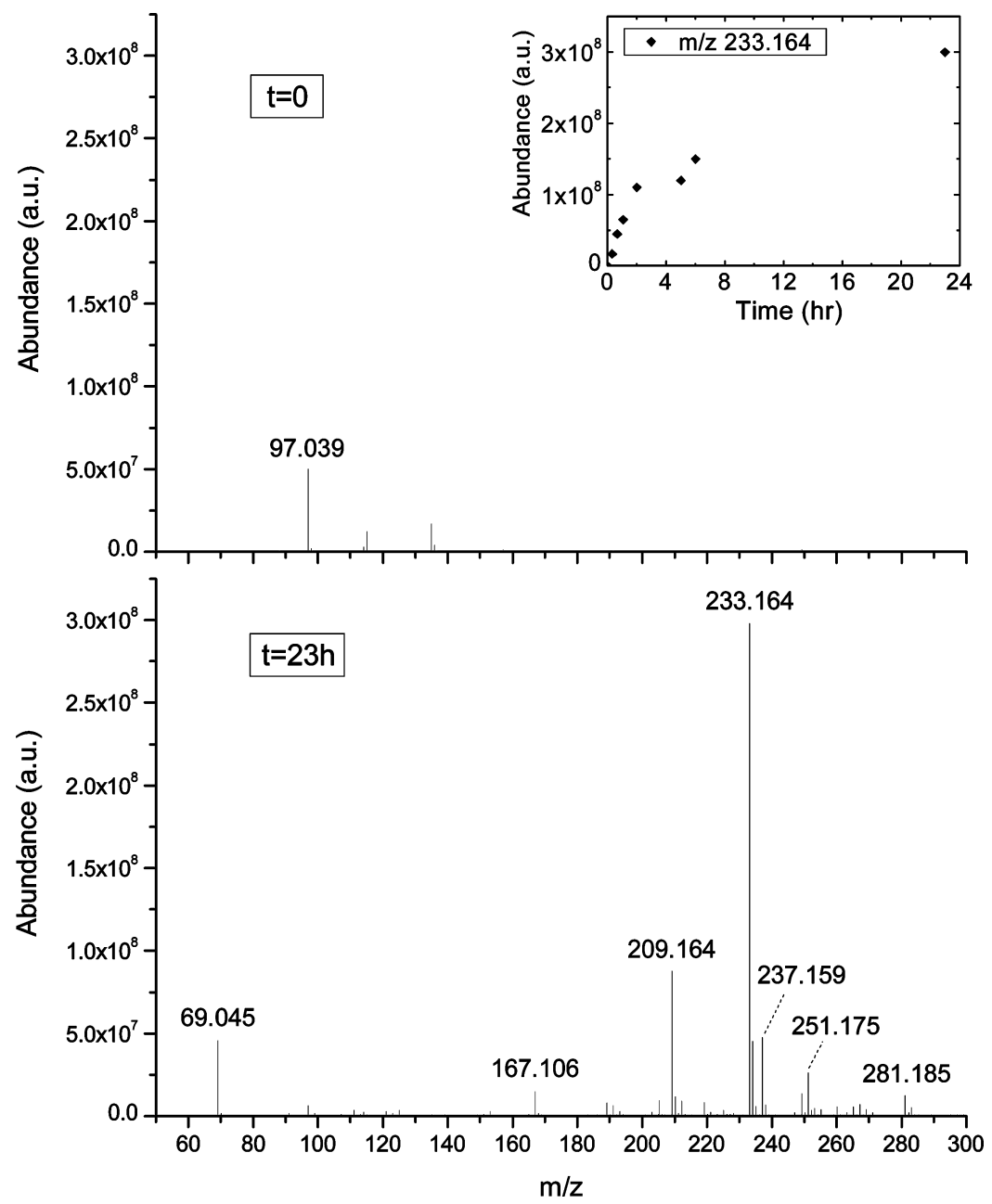

Figure 3. Average mass spectra obtained in (+)ESI-HRMS for bulk experiment at initial time and after $23 \mathrm{~h}$ of irradiation (average on $\sim 70$ spectra on $1 \mathrm{~min}$ acquisition time in direct infusion). Inset: time evolution of $\mathrm{m} / z 233.164$ abundance. 
Photosensitized Aerosol Growth. In order to produce SOA from photosensitization for chemical analysis, flow tube experiments similar to those presented by Aregahegn et al. ${ }^{26}$ were performed. Monodisperse IC/ammonium sulfate aerosol seeds and gaseous limonene were first injected and irradiated. A typical profile for the evolution of the median diameter of the particles at the flow tube outlet is shown in Figure 2. As expected, a significant particle growth was observed when seed particles were exposed to both limonene and UV light. In the dark (from initial time to $\mathrm{A}$ in Figure 2), the median diameter was constant and very close to the seed particle diameter selected at the inlet of the flow tube $(50 \mathrm{~nm})$. Under irradiation, this diameter increased during a period corresponding to the residence time of the aerosol in the flow tube (50 min, from $A$ to $B$ in Figure 2), to reach a value of $68 \mathrm{~nm}$, corresponding to a diameter growth factor of around $25 \%$ (calculated as the ratio of the difference between the final and the initial and final diameters). When the lamps were subsequently turned off (from $\mathrm{C}$ in Figure 2), the median diameter decreased, during a period corresponding to the residence time, returning to its initial value, confirming the key role of light in the growth of IC containing particles exposed to gaseous limonene. The observed growth was consistent with that obtained by Aregahegn et al. ${ }^{26}$ The experimental parameters (seeds composition, limonene concentration, irradiation, and residence time) were consequently chosen to explore the composition of the grown aerosols from an initial polydisperse seed aerosol. This grown aerosol was collected and extracted by the method described in the Experimental Section for chemical analysis.

Photosensitized Radical Formation from ${ }^{3} \mathrm{IC} *$ Bulk and flow tube experiments were performed to identify the major products of the reaction between the IC triplet state and limonene. In the bulk experiments, direct ( \pm ESI-HRMS analysis showed the formation of nitrogen-containing products as well as a range of oxygenated species. Among them, the formation of a major product at $\mathrm{m} / z 233.1643 \pm 0.0001$ was observed in the positive ionization mode (Figure 3 ). The signal intensity for this ion rose faster during the first $2 \mathrm{~h}$ of the experiment than during the last $21 \mathrm{~h}$, however still increasing with time (Figure 3 inset). The high resolution of the instrument coupled with a mass accuracy estimated to be below $4 \mathrm{ppm}$ under our experimental conditions allowed us to identify $\mathrm{C}_{14} \mathrm{H}_{21} \mathrm{ON}_{2}{ }^{+}$(exact mass $233.1648, \Delta \mathrm{ppm}=-2.3$ ) as the unique matching positive ion, which corresponds to a $\mathrm{C}_{14} \mathrm{H}_{20} \mathrm{ON}_{2}$ neutral compound. An $\mathrm{MS}^{2}$ mass spectrum of $m / z$ 233.164 was acquired (Figure 4) and its fragmentation pattern reveals the formation of a major fragment at $\mathrm{m} / z$ 97.0394 \pm 0.0001. This fragment corresponds to a $\mathrm{C}_{4} \mathrm{H}_{5} \mathrm{ON}_{2}{ }^{+}$chemical formula (exact mass 97.0396, $\Delta \mathrm{ppm}=-2.5$ ) and can consequently be attributed to an IC fragment $\left(\mathrm{C}_{4} \mathrm{H}_{4} \mathrm{ON}_{2}\right)$. The compound detected at the exact mass $m / z 233.164$ might thus be a radical-radical recombination product of IC $\left(\mathrm{C}_{4} \mathrm{H}_{4} \mathrm{ON}_{2}\right)$ and limonene $\left(\mathrm{C}_{10} \mathrm{H}_{16}\right)$. This would be consistent with the expected reactivity of the IC triplet state, proceeding most probably via a hydrogen transfer leading to the formation of alkyl radicals. ${ }^{26}$ This hydrogen transfer can be either a direct transfer or proceed via an electron transfer followed by a proton transfer. To account for these results, formation mechanisms proceeding via the photosensitized formation of two radicals, an IC and limonene radical, are hereby suggested (Figure 5). The position of the transferred hydrogen on the limonene structure could be mechanism dependent. In

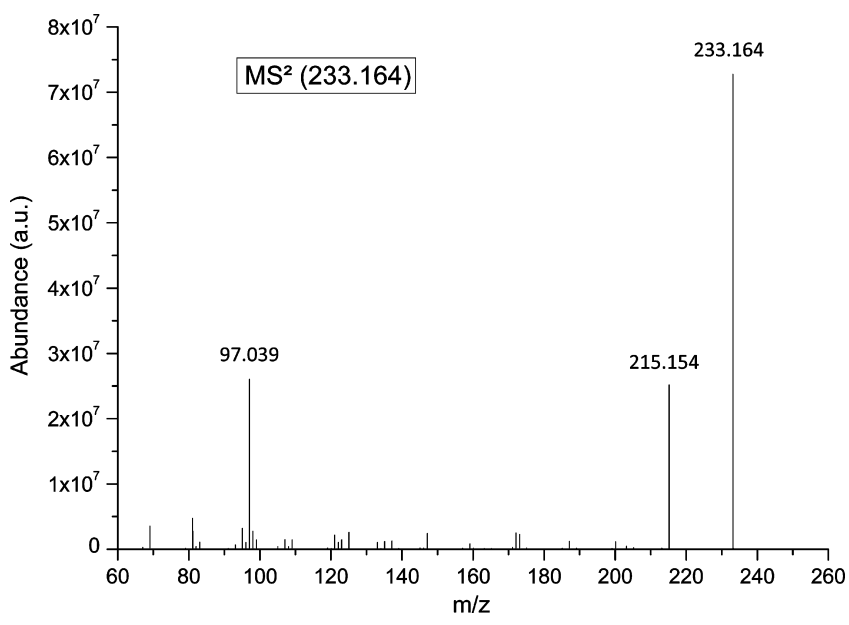

Figure 4. $\mathrm{MS}^{2}$ mass spectrum of $m / z 233.164$ in (+)ESI-HRMS.

principle, the weaker $\mathrm{C}-\mathrm{H}$ bond in the limonene molecule should be on the secondary allylic carbons or on the tertiary allylic carbon. ${ }^{30}$ Accordingly, these hydrogen atoms will be preferentially transferred in case of a direct transfer. If the mechanism proceeds first via an electron transfer, then the abstracted electron will preferentially be located on the endocyclic double bond as the corresponding radical cation is stabilized by both tertiary and secondary carbons. Using the available data, it remains difficult to suggest which of the proposed pathways is most dominant. Furthermore, the chromatographic peak obtained for $\mathrm{m} / z 233.164$ by UPLC/ (+)HESI-HRMS analysis of bulk samples was broad and bore shoulders that could correspond to the formation of several isomers. In any case, the detection of such recombination product(s) highlights the photosensitized formation of radicals from limonene and IC the bulk solutions.

In the flow tube aerosol samples, the mass at $m / z 233.164$ was also observed by means of UPLC/(+)HESI-HRMS analysis, but at a lower level, which precluded a direct quantitative comparison with the bulk experiments. However, two additional masses were also detected i.e., at $m / z 193.072$ and $m / z 191.056$ (Table 1 ). These masses only match with neutral compounds having as chemical formulas $\mathrm{C}_{8} \mathrm{H}_{8} \mathrm{O}_{2} \mathrm{~N}_{4}$ and $\mathrm{C}_{8} \mathrm{H}_{6} \mathrm{O}_{2} \mathrm{~N}_{4}$, respectively, and could therefore correspond to recombination products of $\mathrm{IC}\left(\mathrm{C}_{4} \mathrm{H}_{4} \mathrm{ON}_{2}\right)$ with itself via a pathway depicted in Figure 6. The high IC concentration in the seed particles in the flow tube experiments, results in a high probability of the IC triplet state reacting with another IC molecule leading to hydrogen transfer from the fundamental state to the triplet state. This hydrogen transfer likely involves the carbonyl hydrogen as the corresponding $\mathrm{C}-\mathrm{H}$ bond dissociation energy is in the same order of magnitude as an allylic transfer. ${ }^{30}$ This hydrogen transfer subsequently leads either directly to the recombination of the two just formed radicals to give the recombination product detected at $\mathrm{m} / z$ 193.072, or to the recombination of two radicals having undergone hydrogen abstraction to give the compound detected at $m / z$ 191.056. These two recombination products of IC with itself were not detected in bulk experiments. A simple concentration effect can be invoked here, as in the bulk experiments, IC was 10 times less concentrated than limonene. On the contrary, in flow tube experiments, seed particles were only composed of dry IC and ammonium sulfate exposed to 0.9 
<smiles>C=C(C)C1[CH+]C=C(C)CC1</smiles>

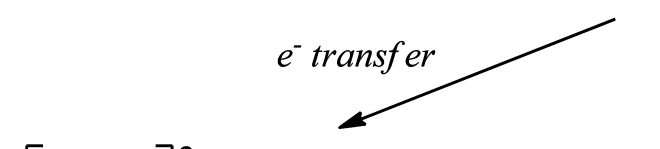<smiles>C=C(C)C1CCC(C)CC1</smiles><smiles>OCc1ncc[nH]1</smiles>

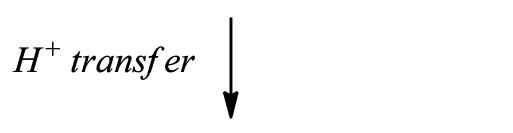

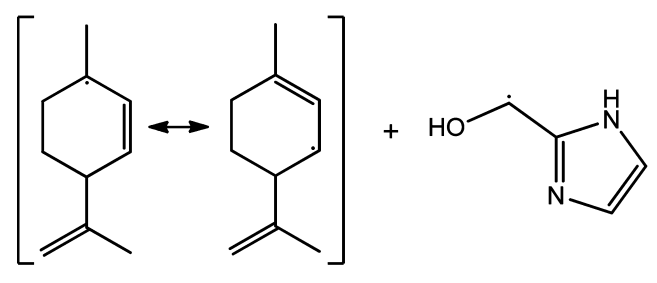<smiles>[R]C([R])=[13C][13CH][13CH]</smiles><smiles>C=C(C)C1C=CC(C)(C(O)c2ncc[nH]2)CC1</smiles><smiles>C=C=C=C</smiles>

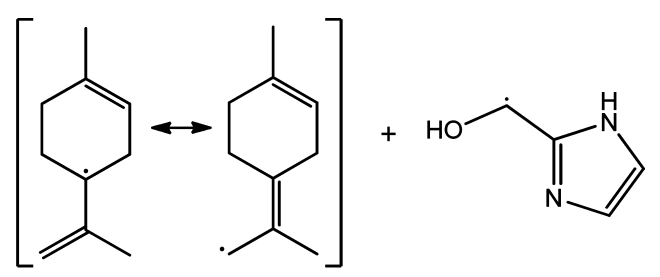

Recombination

Figure 5. Potential formation mechanisms of the recombination product of IC and limonene detected at mass $\mathrm{m} / z 233.164$ in the bulk experiments from molecular limonene and IC triplet state.

ppm of gaseous limonene leading to the predominance of ICIC recombination products over IC-limonene ones.

It is difficult to infer from these experiments if the formation of IC-limonene and IC-IC recombination products is atmospherically relevant as the IC and limonene concentrations used here are high compared to expected atmospheric concentrations. However, the presence of these recombination products both in the bulk and in the flow tube samples indicates that the photosensitized chemistry of IC initiates radical chemistry in the aerosol phase and/or at the gas/particle interface under realistic irradiation conditions. In addition, the results of the bulk experiments showed explicitly that the IC triplet state is able to react with limonene through hydrogen abstraction.

Highly Oxygenated Limonene Oxidation Products. Both bulk and flow tube experiments provided evidence of radical formation from the IC triplet state. Here, results of the flow tube experiments will be preferentially discussed to explain the observed aerosol growth. In addition to the recombination products, the SOA analysis by means of UPLC/(-)HESIHRMS revealed the formation of a range of highly oxygenated products with a majority of compounds bearing between $\mathrm{C}_{8}$ and $\mathrm{C}_{10}$ carbon chains and up to 6 oxygen atoms (Table 1 ). No attempt was made here to elucidate their chemical structure nor to quantify them. However, the fact that these oxygenated products were formed in only $50 \mathrm{~min}$ without any gas phase oxidant is noteworthy. Of particular interest are the compounds that kept the $\mathrm{C}_{10}$ carbon chain of limonene and contained 4 to 6 oxygen atoms, which are remarkable in that they cannot be explained by classical gas-phase ozonolysis or photooxidation chemistry; the terminal double bond of limonene implying necessarily some fragmentation reducing the carbon number. $^{31-33}$ The presence of such compounds clearly shows that limonene reacts in the particle upon uptake and not in the gas phase. The formation of similar oxygenated products was confirmed in the analysis of bulk experiments, with 
Table 1. Detected Exact Masses in the Grown Aerosols Coming from a Flow Tube Experiment by UPLC/( \pm$)$ HESI-MS

\begin{tabular}{|c|c|c|c|c|c|}
\hline ionization mode & detected mass $(m / z)$ & chemical formula $^{a}$ & $R_{\mathrm{t}}(\min )$ & $\operatorname{area}^{b}\left(\times 10^{5}\right.$ a.u. $)$ & light/dark ratio ${ }^{c}$ \\
\hline$(+)$ & 233.164 & $\mathrm{C}_{14} \mathrm{H}_{20} \mathrm{ON}_{2}$ & 7.53 & 26 & 459 \\
\hline$(+)$ & 193.072 & $\mathrm{C}_{8} \mathrm{H}_{8} \mathrm{O}_{2} \mathrm{~N}_{4}$ & 6.61 & 1100 & 101 \\
\hline$(+)$ & 191.056 & $\mathrm{C}_{8} \mathrm{H}_{6} \mathrm{O}_{2} \mathrm{~N}_{4}$ & 5.27 & 820 & 380 \\
\hline$(-)$ & 151.113 & $\mathrm{C}_{10} \mathrm{H}_{16} \mathrm{O}$ & $8.99-9.41$ & $1.7(9.41)$ & 344 \\
\hline$(-)$ & 167.108 & $\mathrm{C}_{10} \mathrm{H}_{16} \mathrm{O}_{2}$ & $7.06-7.31-7.60$ & $7.6(7.31)$ & 89 \\
\hline$(-)$ & 183.102 & $\mathrm{C}_{10} \mathrm{H}_{16} \mathrm{O}_{3}$ & $8.05-8.14$ & $36(8.05)$ & 97 \\
\hline$(-)$ & 181.087 & $\mathrm{C}_{10} \mathrm{H}_{14} \mathrm{O}_{3}$ & 8.35 & 10 & 40 \\
\hline$(-)$ & 199.098 & $\mathrm{C}_{10} \mathrm{H}_{16} \mathrm{O}_{4}$ & 6.88 & 280 & 14 \\
\hline$(-)$ & 197.082 & $\mathrm{C}_{10} \mathrm{H}_{14} \mathrm{O}_{4}$ & 6.64 & 26 & 73 \\
\hline$(-)$ & 215.092 & $\mathrm{C}_{10} \mathrm{H}_{16} \mathrm{O}_{5}$ & $5.80-6.15$ & $86(6.15)$ & 203 \\
\hline$(-)$ & 213.077 & $\mathrm{C}_{10} \mathrm{H}_{14} \mathrm{O}_{5}$ & $6.10-6.46-6.65$ & $19(6.65)$ & 37 \\
\hline$(-)$ & 231.087 & $\mathrm{C}_{10} \mathrm{H}_{16} \mathrm{O}_{6}$ & $4.91-5.14$ & $49(4.91)$ & 1245 \\
\hline$(-)$ & 229.072 & $\mathrm{C}_{10} \mathrm{H}_{14} \mathrm{O}_{6}$ & 5.89 & 11 & 106 \\
\hline$(-)$ & 185.082 & $\mathrm{C}_{9} \mathrm{H}_{14} \mathrm{O}_{4}$ & 7.26 & 330 & 130 \\
\hline$(-)$ & 183.066 & $\mathrm{C}_{9} \mathrm{H}_{12} \mathrm{O}_{4}$ & $5.19-5.31-5.84$ & $15(5.19)$ & 333 \\
\hline$(-)$ & 169.087 & $\mathrm{C}_{9} \mathrm{H}_{14} \mathrm{O}_{3}$ & 7.73 & 26 & 40 \\
\hline$(-)$ & 155.071 & $\mathrm{C}_{8} \mathrm{H}_{12} \mathrm{O}_{3}$ & 6.33 & 23 & 9 \\
\hline$(-)$ & 187.061 & $\mathrm{C}_{8} \mathrm{H}_{12} \mathrm{O}_{5}$ & 5.53 & 220 & 340 \\
\hline
\end{tabular}

${ }^{a}$ Neutral chemical formula corresponding to the positively or negatively charged chemical formula determined form detected exact mass. ${ }^{b}$ In case of several retention times, the area of the main peak is given (peak retention time in brackets). ${ }^{c}$ Ratio of the peak area detected in the irradiated sample on the peak (or the noise) area detected at the same retention time in the nonirradiated sample.

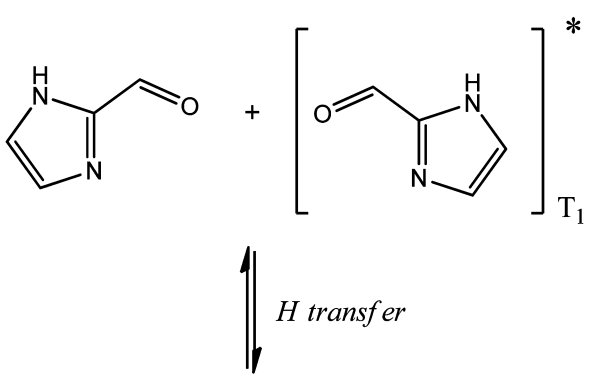<smiles>O=Cc1ncc[nH]1</smiles>

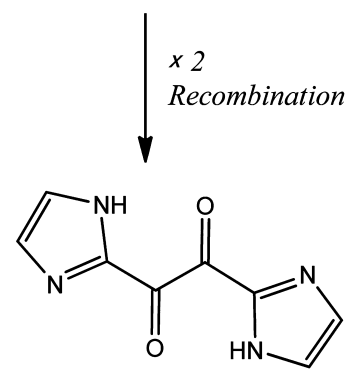

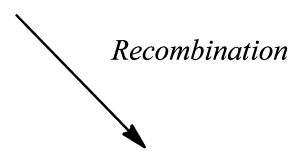

$\mathrm{C}_{8} \mathrm{H}_{6} \mathrm{O}_{2} \mathrm{~N}_{4}$<smiles>O=C(c1ncc[nH]1)C(O)c1ncc[nH]1</smiles>

$$
\mathrm{C}_{8} \mathrm{H}_{8} \mathrm{O}_{2} \mathrm{~N}_{4}
$$

Figure 6. Potential formation mechanisms of the recombination products of IC with itself detected in flow tube sample.

corresponding ion intensities increasing with time. Because of their expected low volatility, due to the presence of up to 6 oxygen atoms on the limonene structure, these oxygenated products are expected to participate to the observed SOA growth.

On the basis of the IC radical chemistry evidenced in this work and the previous observation that molecular oxygen is necessary for SOA growth, ${ }^{26}$ a mechanism explaining the formation of such compounds and based on peroxy radical chemistry is suggested. This mechanism is initiated by the direct abstraction of a hydrogen atom on limonene by the IC triplet state leading to the formation of a stable allylic radical. The addition of molecular oxygen leads to a peroxy radical that can evolve toward a large range of oxidation products, ${ }^{34}$ including compounds retaining the same number of carbons as limonene. As an illustration, the formation mechanism of the three compounds $\mathrm{C}_{10} \mathrm{H}_{16} \mathrm{O}_{4}, \mathrm{C}_{10} \mathrm{H}_{14} \mathrm{O}_{4}$ and $\mathrm{C}_{10} \mathrm{H}_{14} \mathrm{O}_{3}$, detected at $m / z 199.098, m / z 197.082$, and $m / z 181.087$, respectively, is presented in Figure 7 . This mechanism underlines that the observed products are the result, after ring-opening, of intramolecular isomerization (1,5 hydrogen shift $\left.{ }^{35}\right)$ which are particularly favored in the case of limonene. The number of possible 1,5 hydrogen shifts is indeed numerous in the limonene structure because of the chain of 7 carbons and the isopropene side chain. Furthermore, the first step of the mechanism is controlled by the formation of an allylic radical, especially stable in the case of limonene and any other VOC bearing unsaturated tertiary carbon. This mechanism would thus be consistent with the previous observations of Aregahegn et al. $^{26}$ that aerosol growth was mostly observed with this type of compounds.

Atmospheric Implications. Light-induced reactive uptake of VOCs was previously observed and presented as a potentially important atmospheric pathway, but still unaccounted for in SOA mass budget, by Monge et al. $^{25}$ and Aregahegn et al. ${ }^{26}$ However, the data reported here is, to our knowledge, the first proposed photosensitized mechanism based on actual reaction products. In this work, the identification of various recombination products has clearly shown that the presence of IC in the aerosol phase can initiate radical chemistry under near-UV irradiation. The IC triplet state is able to abstract hydrogen from limonene molecules leading to their reactive uptake with subsequent oxidation, and similar mechanisms can be inferred for the other unsaturated and branched VOCs studied by Aregahegn et al. ${ }^{26}$ Such VOCs (i.e., bearing a branched allylic or a branched aromatic 

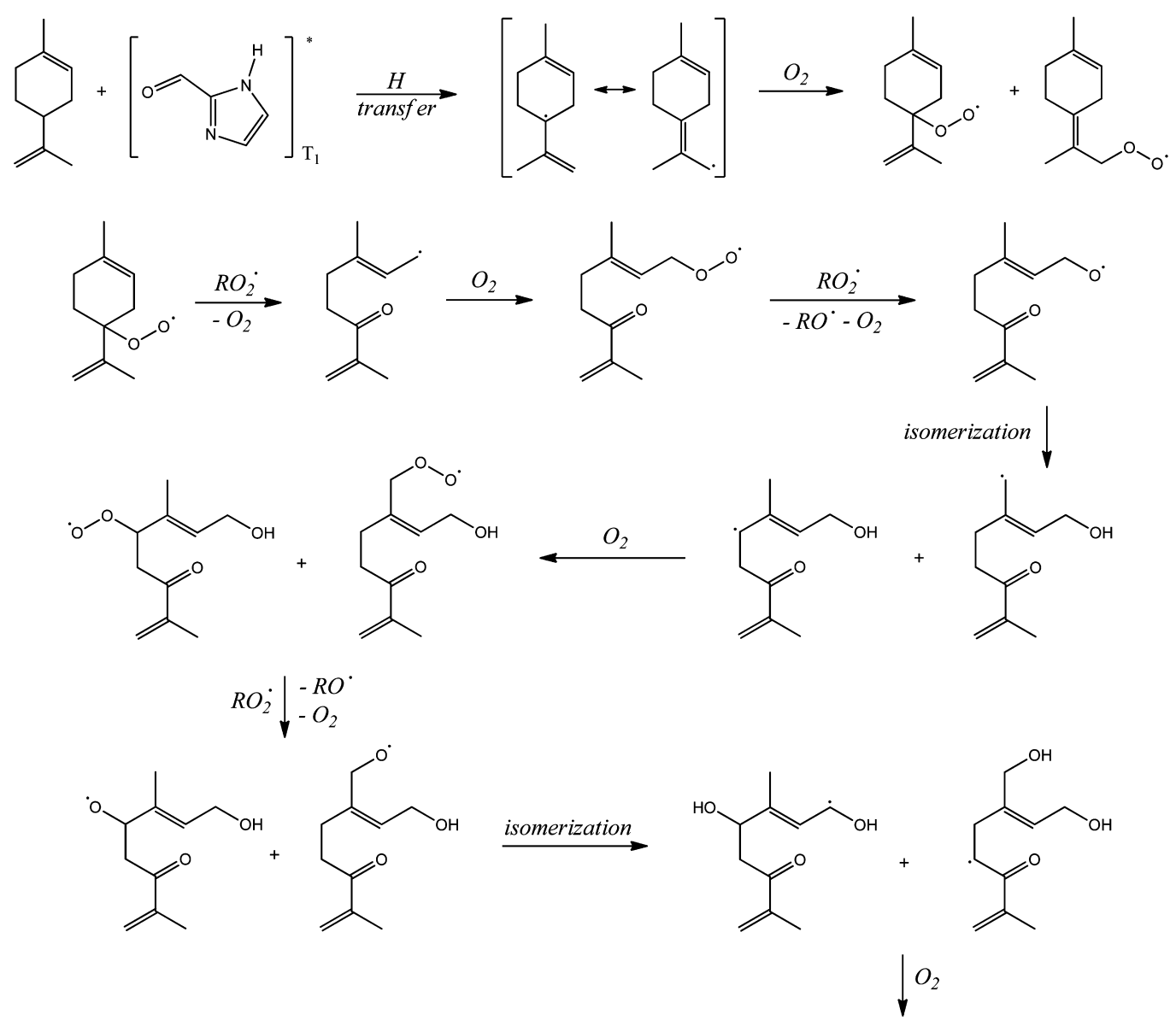<smiles>C=C(C)C(=O)CC(O)C(C)=CC(O)O</smiles><smiles>C=C(C)C(=O)CC(O)/C(C)=C\C=O</smiles>

Figure 7. Limonene photosensitized oxidation mechanism initiated by hydrogen abstraction on limonene molecule through reaction with IC triplet state and based on the peroxy radical chemistry. Example for the formation of three compounds keeping the $\mathrm{C}_{10}$ limonene skeleton by two steps of isomerization.

structure) are emitted in large amounts by biogenic and anthropogenic sources. ${ }^{36-38}$ Their direct uptake into the particulate phase without the need of previous gas phase oxidation and partitioning steps and the subsequent fast formation of highly oxygenated products, could lead to significant SOA formation even if other reactants are present in the particulate phase, ${ }^{26}$ or if photosensitizers are present at trace quantities. Recent studies have shown that IC can indeed be formed within a time scale relevant for atmospheric processes ( 1 to $2 \mathrm{~h}$ ), even if the reaction may not be complete and depends on involved reactant concentrations. ${ }^{21,24,26}$
Furthermore, one may suppose that the recently evidenced near UV light-absorbing material formation via particulate phase chemistry of carbonyls with ammonium ions and amines, ${ }^{17-20,22,39}$ potentially involves a variety of additional still unknown photosensitizers.

Beyond the reactive uptake of VOCs (or even SVOCs bearing hydrogen available for abstraction), in situ photosensitizer formation could also efficiently impact the chemistry of the particulate phase. Until now, the only source of radicals considered for the particulate phase was the transfer of oxidants from the gas phase $\left(\mathrm{OH}, \mathrm{O}_{3}, \mathrm{NO}_{3}\right.$, and halogens), photo- 
Fenton chemistry, and nitrate photolysis. ${ }^{40,41}$ The photoinduced processes studied in this work could represent a previously unaccounted for in situ particulate phase source of radicals. Furthermore, previous works reported experimental evidence potentially supporting such photosensitized processes. $^{21}$ In the SOA produced by glyoxal uptake in the presence of ammonium sulfate seeds, Galloway et al. ${ }^{21}$ observed the formation of IC and, only in the presence of light, the coformation of highly oxidized organic species (e.g., glyoxylic, glycolic, formic acid). As no oxidant was added, no clear origin of these products, $\mathrm{OH}$ or some other radical mechanisms, has been evidenced. Formation of IC could thus be involved. In these experiments, as glyoxal was the only VOC to be added, the reaction of the IC triplet state would have to be with glyoxal. Moreover, this reaction is expected to be as efficient as with limonene because $\mathrm{C}-\mathrm{H}$ bond dissociation energy on an aldehydic carbon is of the same order of magnitude as on an allylic carbon. ${ }^{30}$ In that case, the in situ IC formation via glyoxal reactivity could interestingly be able to influence daytime fate of glyoxal within the particulate phase, enhancing its irreversible loss.

The results of this work suggest that, generally speaking, the presence of photosensitizers in ambient aerosol might influence (1) the daytime SOA growth via the reactive uptake of VOCs and (2) the $\mathrm{O} / \mathrm{C}$ ratio and volatility of the organic fraction of the aerosol via the fast formation of highly oxidized products. As these two points are critical to assess SOA budget and properties, further research is now required to estimate the magnitude of these processes in real environments. In particular, it would be interesting to compare the rate of light-induced uptake of VOCs due to these processes and those of their gas phase oxidation processes. The comparison between these different pathways in the atmosphere could also be based on the identification of different tracers. The identification of other potential photosensitizers is also necessary.

\section{AUTHOR INFORMATION}

\section{Corresponding Author}

*Phone: (33) (0)4 374236 81; fax: (33) (0)4 724484 38; email: christian.george@ircelyon.univ-lyon1.fr.

\section{Notes}

The authors declare no competing financial interest.

\section{ACKNOWLEDGMENTS}

The research leading to these results has received funding from the European Research Council under the European Union's Seventh Framework Programme (FP/2007-2013)/ERC Grant Agreement 290852-AIRSEA.

\section{REFERENCES}

(1) Jimenez, J. L.; Canagaratna, M. R.; Donahue, N. M.; Prevot, A. S. H.; Zhang, Q.; Kroll, J. H.; DeCarlo, P. F.; Allan, J. D.; Coe, H.; Ng, N. L.; Aiken, A. C.; Docherty, K. S.; Ulbrich, I. M.; Grieshop, A. P.; Robinson, A. L.; Duplissy, J.; Smith, J. D.; Wilson, K. R.; Lanz, V. A.; Hueglin, C.; Sun, Y. L.; Tian, J.; Laaksonen, A.; Raatikainen, T.; Rautiainen, J.; Vaattovaara, P.; Ehn, M.; Kulmala, M.; Tomlinson, J. M.; Collins, D. R.; Cubison, M. J. E.; Dunlea, J.; Huffman, J. A.; Onasch, T. B.; Alfarra, M. R.; Williams, P. I.; Bower, K.; Kondo, Y.; Schneider, J.; Drewnick, F.; Borrmann, S.; Weimer, S.; Demerjian, K.; Salcedo, D.; Cottrell, L.; Griffin, R.; Takami, A.; Miyoshi, T.; Hatakeyama, S.; Shimono, A.; Sun, J. Y.; Zhang, Y. M.; Dzepina, K.; Kimmel, J. R.; Sueper, D.; Jayne, J. T.; Herndon, S. C.; Trimborn, A.
M.; Williams, L. R.; Wood, E. C.; Middlebrook, A. M.; Kolb, C. E.; Baltensperger, U.; Worsnop, D. R. Evolution of organic aerosols in the atmosphere. Science 2009, 326, 1525-1529.

(2) Hallquist, M.; Wenger, J. C.; Baltensperger, U.; Rudich, Y.; Simpson, D.; Claeys, M.; Dommen, J.; Donahue, N. M.; George, C.; Goldstein, A. H.; Hamilton, J. F.; Herrmann, H.; Hoffmann, T.; Iinuma, Y.; Jang, M.; Jenkin, M. E.; Jimenez, J. L.; Kiendler-Scharr, A.; Maenhaut, W.; McFiggans, G.; Mentel, T. F.; Monod, A.; Prevot, A. S. H.; Seinfeld, J. H.; Surratt, J. D.; Szmigielski, R.; Wildt, J. The formation, properties and impact of secondary organic aerosol: Current and emerging issues. Atmos. Chem. Phys. 2009, 9, 5155-5236.

(3) Hodzic, A.; Jimenez, J. L.; Madronich, S.; Aiken, A. C.; Bessagnet, B.; Curci, G.; Fast, J.; Lamarque, J. F.; Onasch, T. B.; Roux, G.; Schauer, J. J.; Stone, E. A.; Ulbrich, I. M. Modeling organic aerosols during MILAGRO: Importance of biogenic secondary organic aerosols. Atmos. Chem. Phys. 2009, 9, 6949-6981.

(4) Shrivastava, M.; Lipsky, E. M.; Stanier, C. O.; Robinson, A. L. Modeling semivolatile organic aerosol mass emissions from combustion systems. Environ. Sci. Technol. 2006, 40, 2671-2677.

(5) Robinson, A. L.; Donahue, N. M.; Shrivastava, M. K.; Weitkamp, E. A.; Sage, A. M.; Grieshop, A. P.; Lane, T. E.; Pierce, J. R.; Pandis, S. N. Rethinking organic aerosols: Semivolatile emissions and photochemical aging. Science 2007, 315, 1259-1262.

(6) Dzepina, K.; Volkamer, R. M.; Madronich, S.; Tulet, P.; Ulbrich, I. M.; Zhang, Q.; Cappa, C. D.; Ziemann, P. J.; Jimenez, J. L. Evaluation of recently-proposed secondary organic aerosol models for a case study in Mexico City. Atmos. Chem. Phys. 2009, 9, 5681-5709.

(7) Shrivastava, M.; Fast, J.; Easter, R.; Gustafson, W. I., Jr.; Zaveri, R. A.; Jimenez, J. L.; Saide, P.; Hodzic, A. Modeling organic aerosols in a megacity: Comparison of simple and complex representations of the volatility basis set approach. Atmos. Chem. Phys. 2011, 11, 6639-6662.

(8) Fu, T. M.; Jacob, D. J.; Wittrock, F.; Burrows, J. P.; Vrekoussis, M.; Henze, D. K. Global budgets of atmospheric glyoxal and methylglyoxal, and implications for formation of secondary organic aerosols. J. Geophys. Res.—Atmos. 2008, 113, D15303.

(9) Volkamer, R.; Jimenez, J. L.; San Martini, F.; Dzepina, K.; Zhang, Q.; Salcedo, D.; Molina, L. T.; Worsnop, D. R.; Molina, M. J. Secondary organic aerosol formation from anthropogenic air pollution: Rapid and higher than expected. Geophys. Res. Lett. 2006, 33, L17811.

(10) Volkamer, R.; San Martini, F.; Molina, L. T.; Salcedo, D.; Jimenez, J. L.; Molina, M. J. A missing sink for gas-phase glyoxal in Mexico City: Formation of secondary organic aerosol. Geophys. Res. Lett. 2007, 34, L19807.

(11) Volkamer, R.; Ziemann, P. J.; Molina, M. J. Secondary organic aerosol formation from acetylene $\left(\mathrm{C}_{2} \mathrm{H}_{2}\right)$ : Seed effect on SOA yields due to organic photochemistry in the aerosol aqueous phase. Atmos. Chem. Phys. 2009, 9, 1907-1928.

(12) Waxman, E. M.; Dzepina, K.; Ervens, B.; Lee-Taylor, J.; Aumont, B.; Jimenez, J. L.; Madronich, S.; Volkamer, R. Secondary organic aerosol formation from semi- and intermediate-volatility organic compounds and glyoxal: Relevance of $\mathrm{O} / \mathrm{C}$ as a tracer for aqueous multiphase chemistry. Geophys. Res. Lett. 2013, 40, 978-982. (13) Lim, Y. B.; Tan, Y.; Perri, M. J.; Seitzinger, S. P.; Turpin, B. J. Aqueous chemistry and its role in secondary organic aerosol (SOA) formation. Atmos. Chem. Phys. 2010, 10, 10521-10539.

(14) Ervens, B.; Volkamer, R. Glyoxal processing by aerosol multiphase chemistry: Towards a kinetic modeling framework of secondary organic aerosol formation in aqueous particles. Atmos. Chem. Phys. 2010, 10, 8219-8244.

(15) Loeffler, K. W.; Koehler, C. A.; Paul, N. M.; De Haan, D. O. Oligomer formation in evaporating aqueous glyoxal and methyl glyoxal solutions. Environ. Sci. Technol. 2006, 40, 6318-6323.

(16) Hastings, W. P.; Koehler, C. A.; Bailey, E. L.; De Haan, D. O. Secondary organic aerosol formation by glyoxal hydration and oligomer formation: Humidity effects and equilibrium shifts during analysis. Environ. Sci. Technol. 2005, 39, 8728-8735.

(17) Nozière, B.; Dziedzic, P.; Córdova, A. Products and kinetics of the liquid-phase reaction of glyoxal catalyzed by ammonium ions $\left(\mathrm{NH}_{4}^{+}\right)$. J. Phys. Chem. A 2009, 113, 231-237. 
(18) Kampf, C. J.; Jakob, R; Hoffmann, T. Identification and characterization of aging products in the glyoxal/ammonium sulfate system - implications for light-absorbing material in atmospheric aerosols. Atmos. Chem. Phys. 2012, 12, 6323-6333.

(19) Shapiro, E. L.; Szprengiel, J.; Sareen, N.; Jen, C. N.; Giordano, M. R.; McNeill, V. F. Light-absorbing secondary organic material formed by glyoxal in aqueous aerosol mimics. Atmos. Chem. Phys. 2009, 9, 2289-2300.

(20) Bones, D. L.; Henricksen, D. K.; Mang, S. A.; Gonsior, M.; Bateman, A. P.; Nguyen, T. B.; Cooper, W. J.; Nizkorodov, S. A. Appearance of strong absorbers and fluorophores in limonene- $\mathrm{O}_{3}$ secondary organic aerosol due to $\mathrm{NH}_{4}{ }^{+}$-mediated chemical aging over long time scales. J. Geophys. Res.-Atmos. 2010, 115, D05203.

(21) Galloway, M. M.; Chhabra, P. S.; Chan, A. W. H.; Surratt, J. D.; Flagan, R. C.; Seinfeld, J. H.; Keutsch, F. N. Glyoxal uptake on ammonium sulphate seed aerosol: Reaction products and reversibility of uptake under dark and irradiated conditions. Atmos. Chem. Phys. 2009, 9, 3331-3345.

(22) De Haan, D. O.; Hawkins, L. N.; Kononenko, J. A.; Turley, J. J.; Corrigan, A. L.; Tolbert, M. A.; Jimenez, J. L. Formation of nitrogencontaining oligomers by methylglyoxal and amines in simulated evaporating cloud droplets. Environ. Sci. Technol. 2011, 45, 984-991.

(23) Trainic, M.; Riziq, A. A.; Lavi, A.; Flores, J. M.; Rudich, Y. The optical, physical and chemical properties of the products of glyoxal uptake on ammonium sulfate seed aerosols. Atmos. Chem. Phys. 2011, 11, 9697-9707.

(24) Yu, G.; Bayer, A. R.; Galloway, M. M.; Korshavn, K. J.; Fry, C. G.; Keutsch, F. N. Glyoxal in aqueous ammonium sulfate solutions: Products, kinetics and hydration effects. Environ. Sci. Technol. 2011, 45, 6336-6342.

(25) Monge, M. E.; Rosenørn, T.; Favez, O.; Müller, M.; Adler, G.; Abo Riziq, A.; Rudich, Y.; Herrmann, H.; George, C.; D’Anna, B. Alternative pathway for atmospheric particles growth. Proc. Natl. Acad. Sci. U.S.A. 2012, 109, 6840-6844

(26) Aregahegn, K. Z.; Noziere, B.; George, C. Organic aerosol formation photo-enhanced by the formation of secondary photosensitizers in aerosols. Faraday Discuss. 2013, 165, 123-134.

(27) Canonica, S.; Jans, U.; Stemmler, K.; Hoigne, J. Transformation kinetics of phenols in water: Photosensitization by dissolved natural organic material and aromatic ketones. Environ. Sci. Technol. 1995, 29, $1822-1831$

(28) Jammoul, A.; Dumas, S.; D’Anna, B.; George, C. Photoinduced oxidation of sea salt halides by aromatic ketones: A source of halogenated radicals. Atmos. Chem. Phys. 2009, 9, 4229-4237.

(29) Tinel, L.; Dumas, S.; George, C. A time resolved study of the multiphase chemistry of excited carbonyls: Imidazole-2-carboxaldehyde and halides. C. R. Chim. 2013.

(30) Blanksby, S. J.; Ellison, G. B. Bond dissociation energies of organic molecules. Acc. Chem. Res. 2003, 36, 255-263.

(31) Leungsakul, S.; Jeffries, H. E.; Kamens, R. M. A kinetic mechanism for predicting secondary aerosol formation from the reactions of D-limonene in the presence of oxides of nitrogen and natural sunlight. Atmos. Environ. 2005, 39, 7063-7082.

(32) Jaoui, M.; Corse, E.; Kleindienst, T. E.; Offenberg, J. H.; Lewandowski, M.; Edney, E. O. Analysis of secondary organic aerosol compounds from the photooxidation of D-limonene in the oresence of $\mathrm{NO}_{x}$ and their detection in ambient $\mathrm{PM}_{2.5}$. Environ. Sci. Technol. 2006, 40, 3819-3828.

(33) Chacon-Madrid, H. J.; Donahue, N. M. Fragmentation vs. functionalization: Chemical aging and organic aerosol formation. Atmos. Chem. Phys. 2011, 11, 10553-10563.

(34) von Sonntag, C.; Schuchmann, H.-P. The elucidation of peroxyl radical reactions in aqueous solution with the help of radiationchemical methods. Angew. Chem., Int. Ed. 1991, 30, 1229-1253.

(35) Atkinson, R. Gas-phase tropospheric chemistry of volatile organic compounds 0.1. Alkanes and alkenes. J. Phys. Chem. Ref. Data 1997, 26, 215-290.
(36) Tsigaridis, K.; Kanakidou, M. Global modelling of secondary organic aerosol in the troposphere: A sensitivity analysis. Atmos. Chem. Phys. 2003, 3, 1849-1869.

(37) Seinfeld, J. H.; Pankow, J. F. Organic atmospheric particulate material. Annu. Rev. Phys. Chem. 2003, 54, 121-140.

(38) Guenther, A.; Karl, T.; Harley, P.; Wiedinmyer, C.; Palmer, P. I.; Geron, C. Estimates of global terrestrial isoprene emissions using MEGAN (Model of Emissions of Gases and Aerosols from Nature). Atmos. Chem. Phys. 2006, 6, 3181-3210.

(39) Updyke, K. M.; Nguyen, T. B.; Nizkorodov, S. A. Formation of brown carbon via reactions of ammonia with secondary organic aerosols from biogenic and anthropogenic precursors. Atmos. Environ. 2012, 63, 22-31.

(40) Chevallier, E.; Jolibois, R. D.; Meunier, N.; Carlier, P.; Monod, A. "Fenton-like" reactions of methylhydroperoxide and ethylhydroperoxide with $\mathrm{Fe}^{2+}$ in liquid aerosols under tropospheric conditions. Atmos. Environ. 2004, 38 (4), 921-933.

(41) Nguyen, T. B.; Coggon, M. M.; Flagan, R. C.; Seinfeld, J. H. Reactive uptake and photo-fenton oxidation of glycolaldehyde in aerosol liquid water. Environ. Sci. Technol. 2013, 47 (9), 4307-4316. 